\title{
Dental Treatment of Marfan Syndrome. With regard to a case
}

\author{
Mariana-Carolina Morales-Chávez ${ }^{1}$, María-Verónica Rodríguez-López ${ }^{2}$ \\ ${ }^{1}$ Pediatric Dentist. Magister in Patients with Special needs. Valencia University, Spain Asistant Professor of Pediatric Dentistry \\ Department, Santa María University, Venezuela \\ Pediatric Dentist \\ Correspondence: \\ Avenida La Guairita con Calle Trinidad.
}

Centro Profesional Vizcaya Piso 3. Ofic. 3-7.

Colinas del Tamanaco. Caracas. CP 1061. Venezuela

macamocha@hotmail.com

Received: 28/02/2010

Accepted: $27 / 06 / 2010$

Morales-Chávez MC, Rodríguez-López MV. Dental Treatment of Marfan Syndrome. With regard to a case. Med Oral Patol Oral Cir Bucal. 2010 Nov 1;15 (6):e859-62.

http://www.medicinaoral.com/medoralfree01/v15i6/medoralv15i6p859.pdf

Article Number: 16907 http://www.medicinaoral.com/

(C) Medicina Oral S. L. C.I.F. B 96689336 - pISSN 1698-4447 - eISSN: 1698-6946

eMail: medicina@medicinaoral.com

Indexed in:

-SCI EXPANDED

-JOURNAL CITATION REPORTS

-Index Medicus / MEDLINE / PubMed

-EMBASE, Excerpta Medica

-SCOPUS

-Indice Médico Español

\begin{abstract}
Marfan syndrome is the most common dominant autosomic genetic disorder of the connective tissue. It has a reported incidence of 1 per each 5000 individuals without any distinction of gender or ethnicity. This pathology's diagnosis is mainly based on physical characteristics, presenting three main different symptomatic charts: neonatal Marfan, infant Marfan and classical Marfan. The mayor characteristic of these patients consists of an exaggerated length of the upper and lower limbs, hyperlaxity, scoliosis, alterations in the cardiovascular and pulmonary systems and atypical bone overgrowth. The individual implied in the present investigation concerned to a 14 year old male patient presenting multiple mouth lesions and dental alterations, attended in the Department of Pediatric Dentistry degree at the Dentistry School in the Santa Maria University. The patient has been treated following the necessary considerations required according to his systemic compromise $d$ under oral premedication for decrease the anxiety and make easear the behavior management. The patirnt with MS has multiple oral decrease that may be diagnoticated a treated on time to increase the life quality of the patient.
\end{abstract}

Key words: Marfan syndrome, dental management, oral premedication, patients with special needs.

\section{Introduction}

Marfan Syndrome (MS) was firstly described by the pediatrician Antoine Bernard-Jean Marfan who reported an out of proportioned length of the lower limbs and fingers (1). The MS is a dominant autosomic genetic disorder which affects the elastic fibers of the connective tissue, showing itself in those systems/organs holding it, such as the cardiovascular, skeletal, dura mater, ocular, skin, teguments and lung $(2,3)$. This is mainly caused of mutations in the fibrilin glycoprotein's codified gene -1 located in the chromosome 15q21 $(1,4)$. It has been described that the normal fibrilin inhibits the growth of the long bones and elastic fibers, through its tension control the growth of these, because of it, at these structures being altered, an exaggerated bone overgrowth is produced that better characterizes this 
01 decease (2). This condition represents an incidence of 1 02 per each 5000/9800 individuals without any gender or 03 ethnic distinction $(1,-4)$.

$04 \mathrm{MS}$ is a multi-systemic disorder with typical manifes05 tations which affect the skeletal, cardiovascular and 06 ocular systems. On a skeletal level, an out of propor07 tioned overgrowth of the long bones is observed which 08 is frequently considered to be the most highlighted and 09 evident feature. Nevertheless, other signs like pectum 10 scavatum, scoliosis, articular hipermovility and flat 11 foot may be presented. The cardiovascular pathology 12 most frequently presented is the dilatation of the as13 cending aorta on the aortic sinuses level. These lesions 14 constitute the main cause of mobility and mortality for 15 patients with MS. The ocular system has been shown 16 to be generally affected with a dislocation of the lens, 17 however, several other pathologies can be developed 18 such as cataracts or glaucoma $(3,4)$.

19 A narrow cranium is present on the craniofacial area, 20 with dolichocephaly features, deep palatal, jammed 21 teeth, retrognathia or micrognathia, flat molars and de22 scendant palpebral fissures. This type of paladar may ent occasions, because of 2 birth inguinal hernias at the time he was 9 months old, from tonsils and adenoids (3 years old) and an elongation of the calcaneus on the left foot respectively.

After the data collection corresponding the clinical history and the appropriate signature from the representative concerning to her informed consent, in compliance with the ethical rules of the institution, a clinical exam was carried out.

For the physical examination, a seize of $1,80 \mathrm{~cm}$. range was determined from upper to average (Fig. 1) In the extra-oral examination, some syndrome-typical features were observed, such as an elongated/narrowed cranium or docichocephalism and very elongated limbs. Intra-orally, a very deep palatal was observed, Class II molar relationship by Angle and lack of space for all of the dental structures for which the incisive upper laterals were palatinized in relation to the centrals. Likewise, a presence of a generalized gingivitis associated to the dentobacterial plate and cavities in the 1.6 and 2.6 was observed. Furthermore, on a radiographical level, radicular cysts with radicular dilacerations between the 4.5 and 4.6 and agenesia for the second and third lower molars were present (Fig. 2, 3).

The dental treatment was performed under local anestethic using a maximun of 2 carpuls with vasoconstrictor because of the cardiovascular pathology. It consisted in the placement of a resin in the 1.6, a realization of an endodontic treatment on the 2.6 level with a posterior re-establishment, tartrectomy and exodoncy of

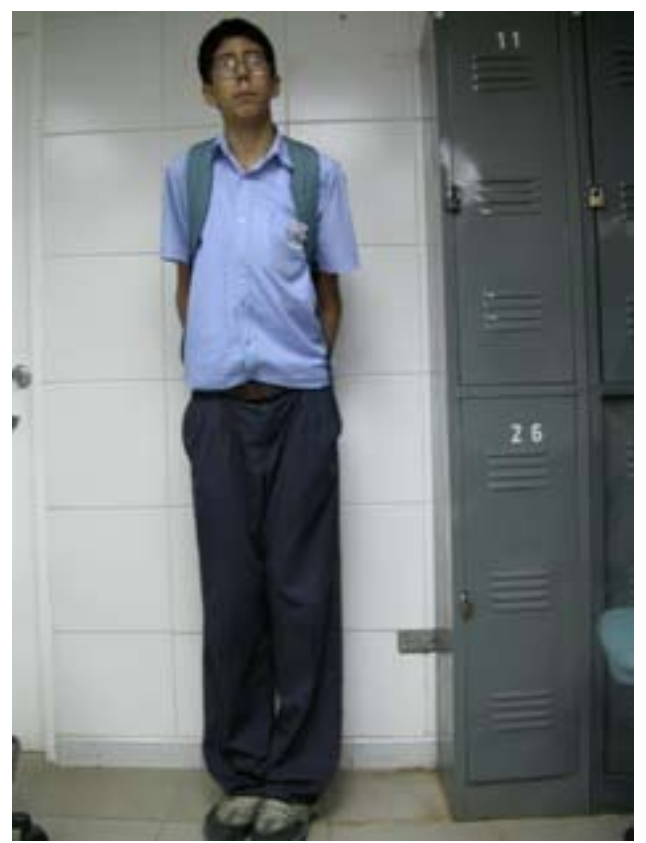

Fig. 1. Physical Characteristics of Marfan Syndrome. The long extremities are evident. 


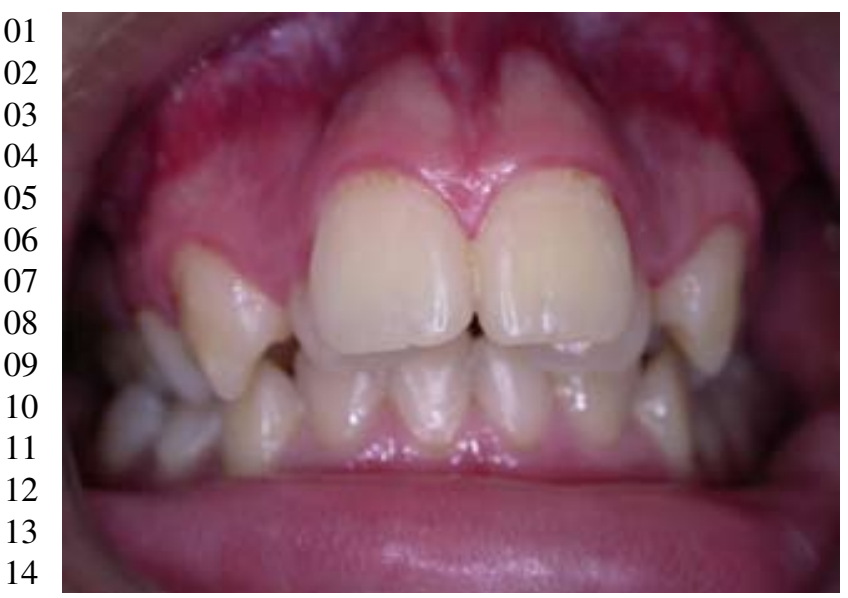

15 Fig. 2. Intraoral aspect. Front side. A gingivitis with dental plaque is 16

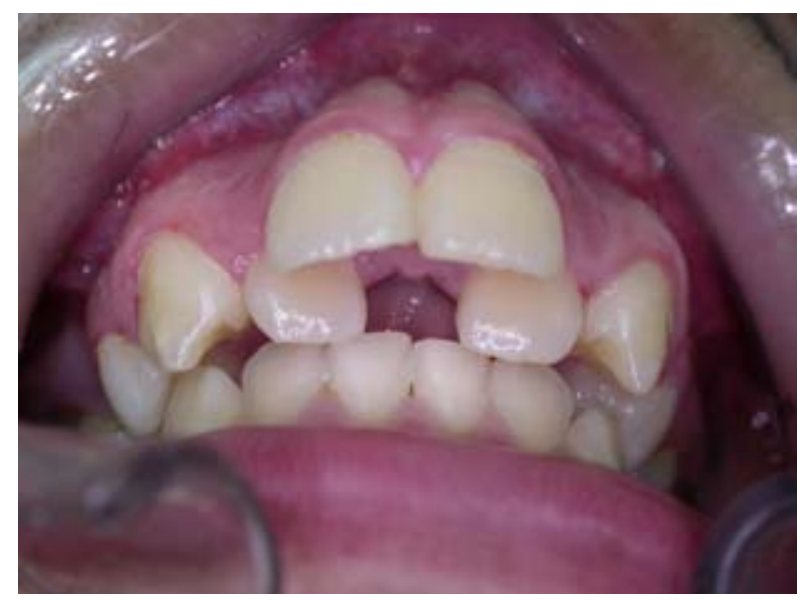

Fig. 3. Lateral incisor are not linning up because of the little transverse development of the maxilar.

eration of the cardiac function and an increase in the cardiac output. It is also very common in these patients the presence of inguinal hernias, as observed in the exposed case, which had two.

On a craniofacial level, the palatal of the Marfan Syndrome is deep and stretch and both jawbones present retrognathia. Westilng and cols (5) studied 76 patient with this syndrome, observing in the $70 \%$ of them a dental collapse and an excessive increase of the over-jet, due to the minor jawbone development. These features are observed on a same manner in the present case. Related to the dental characteristics, De Coster and cols (8) report that in one population of 23 patients with MS, the majority presented a mayor risk of cavities and also a very high difficulty of treatment, because the existence of enamel hypoplasia, radicular deformities, and abnormal form of the pulp chamber. In the same way, they establish that the periodontal disease is presented with a higher frequency and severity in these patients. In the presented case, the patient had a generalized gingivitis mainly associated to plaque. As previously described in other reports, the patient presented a dilacerated radicular rest. No obliteration was found when performing endodontic treatment $(7,8)$. Regarding to Temporomandibular Alterations, Bauss $\mathrm{O}$ et al (13) reported a prevalence of $51.6 \%$ of articular disfunction and $24.2 \%$ of subluxation. (Table 1).

Patients with MS present endless medical compromises and mouth alterations that difficulty the overall dental treatment. Because of its medical conditions, a mayor predisposition to develop dental cavities, periodontal deceases and malocclusions are created. Early diagnoses of both dental and craniofacial anomalies, as well as an opportune appliance of an adequate treatment, could definitely develop a satisfactory prognosis of these type of patients, considerably improving their life quality. 
40 4. Dean JC. Management of Marfan syndrome. Heart. 2002;88:97-

41103.

42 5. Westling L, Mohlin B, Bresin A. Craniofacial manifestations in 42 the Marfan syndrome: palatal dimensions and a comparative cepha-

44 6. Utreja A, Evans CA. Marfan syndrome-an orthodontic perspec-

45 tive. Angle Orthod. 2009;79:394-400.

Tabe 1. Oral Manifestation in Marfan Syndrome.

\section{References}

1. Shirley ED, Sponseller PD. Marfan syndrome. J Am Acad Orthop Surg. 2009;17:572-81. Clin Genet. 2009;76:25-37.

Ammash NM, Sundt TM, Connolly HM. Marfan syndrome-diagsis and management. Curr Probl Cardiol. 2008;33:7-39.

metric analysis. J Craniofac Genet Dev Biol. 1998;18:211-8. in patients with Marfan syndrome. Oral Surg Oral Med Oral Pathol Oral Radiol Endod. 2008;106:e56-61.

\begin{tabular}{|l|l|}
\hline \multicolumn{1}{|c|}{ Authors } & \multicolumn{1}{|c|}{ Oral Manifestations } \\
\hline Westing L, Mohlin B, Bresin A; 1998 (5) & $\begin{array}{l}\text { Reported deep palate and maxilar and } \\
\text { mandibular retrognatia in 70\% of the } \\
\text { evaluated patients. }\end{array}$ \\
\hline $\begin{array}{l}\text { De Coster PJ, Martens LC, De Paepe A; } 2002 \\
\text { (8) }\end{array}$ & $\begin{array}{l}\text { Reported a higher caries prevalence in } \\
\text { patients from 0 to 17 years. } \\
\text { High prevalence of hipoplasic stains. }\end{array}$ \\
\hline $\begin{array}{l}\text { Radicular deformation and pulp obliteration. } \\
\text { 2002 (9) }\end{array}$ & High gingival index and calculus \\
\hline $\begin{array}{l}\text { Bauss O, Sadat-Khonsari R, Fenske C, Engelke } \\
\text { W; 2004 (13) }\end{array}$ & $\begin{array}{l}\text { Reported a case of a 41 years old patient with } \\
\text { severe periodontitis, 5.6 mm of insertion loss, } \\
\text { bone loss and dental mobility. } \\
\text { disfunction, subluxation and anterior } \\
\text { displacement of articular disk in 21 patients } \\
\text { with MS. }\end{array}$ \\
\hline Bauss O, Neter D, Rahman A; 2008 (7) & $\begin{array}{l}\text { High prevalence of pulpolitos and pulp } \\
\text { obliteration in patients with MS. }\end{array}$ \\
\hline witreja A, Evans CA; 2009 (6) & $\begin{array}{l}\text { Described 2 patients with severe Periodontitis } \\
\text { without local factors. }\end{array}$ \\
\hline
\end{tabular}

8. De Coster PJ, Martens LC, De Paepe A. Oral manifestations of patients with Marfan syndrome: a case-control study. Oral Surg Oral Med Oral Pathol Oral Radiol Endod. 2002;93:564-72.

9. Straub AM, Grahame R, Scully C, Tonetti MS. Severe periodontitis in Marfan's syndrome: a case report. J Periodontol. 2002;73:823-6.

10. Planells del Pozo P, Barra Soto MJ, Santa Eulalia Troisfontaines E. Antibiotic prophylaxis in pediatric odontology. An update. Med Oral Patol Oral Cir Bucal. 2006;11:E352-7.

11. Tornos P. [Infective endocarditis: Are we managing our patients well?]. Rev Esp Cardiol. 2002;55:789-90.

12. Hirota Y, Sugiyama K, Niwa H, Matsuura H. Systemic management of Marfan's syndrome during dental treatment: a case report. Anesth Pain Control Dent. 1993;2:162-70.

13. Bauss O, Sadat-Khonsari R, Fenske C, Engelke W, SchwestkaPolly R. Temporomandibular joint dysfunction in Marfan syndrome. Oral Surg Oral Med Oral Pathol Oral Radiol Endod. 2004;97:592-8. 